\title{
筋肉タンパク質のリン酸化とカルモデュリン
}

\section{平滑筋の収編, 張力の発生にカルモデュリン体存のリン酽化が必須}

筋肉の収縮蛋白質のらちで，プロテインキナーゼによ るリン酸化を受けることが確認されているるのはミオシ ンとトロポニンIである. トロポニンのリン酸化は, cAMP 依存性キナーゼによるものであるが, ミオシン のリン酸化は $\mathrm{Ca}^{2+}$ 依存性キナーゼにより触媒される. 筋収縮の引き金となる細胞内 $\mathrm{Ca}^{2+}$ 濃度の増加に応答し て起こるミオシンのリン酸化は, 収縮制御に直接関与す ることが期待される.

ミオシン分子は, 分子量 20 万の重鎖と, 分子量 2 万 前後の 2 種の軽鎖とがそれぞれ 1 対ずつ会合した 6 量体 である.リン酸化されるのは，2種の軽鎖のらちの1つ で $\mathrm{P}$ 軽鎖と呼ばれる．P軽鎖のリン酸化を触媒するミ オシン軽鎖キナーゼ (MLCK) は, $\mathrm{Ca}^{2+}$ 受容蛋白質カル モデュリンと $\mathrm{Ca}^{2+}$ とが存在するときにのみ活性を示 す. 筋肉細胞が刺激を受けて細胞質の遊離の $\mathrm{Ca}^{2+}$ 濃度

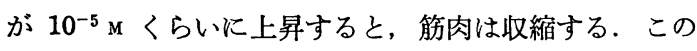
とき， $\mathrm{Ca}^{2+}$ 濃度の上昇とともに，トロポニンやカルモデ ニリンに $\mathrm{Ca}^{2+}$ が結合する. カルモデュリンは $\mathrm{Ca}^{2+}$ と 結合すると，紫外吸収や CD スペクトル変化でとら兄 られるような立体構造変化を生じ，その結果 MLCK と 結合できるようになる。こうして $\mathrm{Ca}^{2+}$-カルモデュリン 複合体と結合した MLCK がキナーゼ活性を示す.

ここで, 骨格筋と平滑筋の収縮に共役するアクトミオ シン ATPase 系の性質を大まかに比較しておこう. 骨 格筋ではアクトミオシン ATPase 活性は, $\mathrm{Ca}^{2+}$ があっ てもなくても高い值を示す，高いATPase 活性は，高い 收縮活些に対応すると見なしてよいので，骨格筋はもと もと縮むように作られていると言える． $\mathrm{Ca}^{2+}$ 受容蛋白 質トロポニンCを含む制御蛋白質を加えると， $\mathrm{Ca}^{2+}$ を 加えない場合に ATPase 活性は低くなり，收縮現象に $\mathrm{Ca}^{2+}$ 依存性がみとめられるようになる。これらの性質 は，ミオシンをリン酸化してもほとんど差が見られな い.カルモデュリン含量はトロポニンCの約 $1 / 10$ で, MLCK 含量も低い。これに対して平滑筋では, アクト ミオシン ATPase 活性は $\mathrm{Ca}^{2+}$ があってもなくても低い
值を示す． ミオシンをリン酸化すると， $\mathrm{Ca}^{2+}$ の存在の いかんにかかわらず高い ATPase 活性を示すようにな る. 骨格筋のトロポニンに相当する制御蛋白質の存在は 今のところ確定的とは言えないので, ATPase の $\mathrm{Ca}^{2+}$ 感受性は $\mathrm{P}$ 軽鎖のリン酸化に関わるMLCK-カルモデュ リンの $\mathrm{Ca}^{2+}$ 依存性に置きかえて考学られている，カル モデュリン含量は高く，骨格筋のトロポニンC 含量に匹 敵する. MLCK 含量も骨格筋の場合の約 10 倍である. 平滑筋ミオシン線維は, ATP 添加により溶解してしま らといら，骨格筋にはない性質をもつが, リン酸化ミオ シンからできるミオシン線維は ATP 存在下でも安定に 存在できる.したがって，カルモデュリンに依存した $\mathrm{P}$ 軽鎖のリン酸化は，平滑筋では 2 通りの役割をるつと考 えられる。

$\mathrm{Ca}^{2+}$-カルモデュリンに依存した $\mathrm{P}$ 軽鎖のリン酸化が, 筋収縮に必須の第 1 段階かどうかを判定する 1 つの方法 は, 刺激を与えた後のリン酸化反応と筋収縮現象とを経 時的に追跡して比較するといらやり方である.

平滑筋片を $\mathrm{KCl}$ 液, あるいは Cholinergic drug 溶 液に入れると, 収縮し張力を発生する。このとき， P軽 鎖のリン酸化は張力発生に先立って起こると報告されて いる. ブタ動脈平滑筋片を $109 \mathrm{mM} \mathrm{K} \mathrm{K}^{+}$を含む生理的塩 溶液につけると， 30 秒後には $\mathrm{P}$ 軽鎖りリン酸化量は最 大 $(0.7 \mathrm{~mol} \mathrm{P} / \mathrm{mol})$ になる. 張力は約 2 分後に最大值に 達して, その後約 2 時間は同じ值を持続する(1). この結 果は, 平滑筋ではカルモデュリンに依存したミオシンの リン酸化が, 収縮開始に必須の段階である可能性を示し ている.この測定をさらに続けると, 30 秒後に最大とな った $\mathrm{P}$ 軽鎖のリン酸化量はその後徐々に減少し，約 20 分後には収縮開始前の值に近い定常值 $(0.2 \mathrm{~mol} / \mathrm{mol})$ に達する. この間, 張力の大きさは前述のように最大值 を維持しているのに, 筋短縮速度は $\mathrm{P}$ 軽鎖のリン酸化量 に並行して減少することが示された。

一般に, 筋短縮速度は ATPase 活性の大きさに見合 った, 単位時間当たりのミオシンとアクチンの結合・解 
離の繰返しの頻度の大きさで決まり，筋の発生張力の大 きさはミオシン・アクチン間の結合の数の大きさで決ま ると考えられている. Dillon ら ${ }^{(1)}$ は，上記の結果とこの 考え方を基礎にして，カルモデュリンに制御される平滑 筋ミオシンのリン酸化の役割を推定した.リン酸化は大 きな短縮速度を得るために必須である，最大値に達した 張力を維持するためには，ミオシンはアクチンと結合し たままになっていればよいので, アクチンがミオシンに 結合したままの状態で脱りン酸化が起こる.Latch mechanism と呼ばれるこの考え方は，低エネルギー消費量で 大きな張力を維持するという動脈の特徵をも強調してい て興味深い. Silver と Stull ${ }^{(2)}$ はウシ気管平滑筋につい て同様の結果を得たので，この機構が平滑筋一般に共通 のものであろうと述べている.

Murphy らは，眖䩗筋線維を使った実験から ${ }^{(1)} ， \mathrm{P}$ 軽 鎖のリン酸化により筋線維上に $\mathrm{Ca}^{2+}$ 結合サイトが露出 し, ここへの $\mathrm{Ca}^{2+}$ の強い結合が脱りン酸化後の張力の 維持に効いているという可能性を示した．平滑筋ミオシ ンのリン酸化は安定なミオシン線維をつくるのに必要で あるという実験結果 ${ }^{(3)}$ や，平滑筋には“トロポニン”は 存在しないのかという問題との関連がこれから明らかに されねばならない点である。

骨格筋でも同様の測定がされている、ラット骨格筋を $200 \mathrm{~Hz} ， 1$ 秒間刺激すると，張力の発生は瞬時のうちに 終了するが，P 軽鎖のリン酸化はその後も増え続け，約
7 秒で最大值 $(0.7 \mathrm{~mol} / \mathrm{mol})$ に達する. その後約 5 分 で, 静止時のリン酸化量 $(0.1 \sim 0.2 \mathrm{~mol} / \mathrm{mol})$ に戻る. この結果は, 骨格筋ではミオシンのリン酸化は収縮開始 に必須ではないことを示している．刺激に対するトロポ ニン系の応答に比べると，カルモデュリン系の応答は遅 く, 骨格筋の速い応答には機能していないということに なる。

しかし、ここで得られるリン酸化量の異なる各状態で $5 \sim 10 \mathrm{~Hz}$ の弱い刺激を与えると，発生する単収縮張力 はリン酸化量が大きいほど大きいという，単収縮の張力 は、トロポニンではなくカルモデュリン系で制御されて いるといら仮説である(4). 単収縮のもつ生理的役割との 関連でこれからの発展が期待される.

このように，平滑筋と比べると骨格筋の場合，ミオシ ンのリン酸化の役割は明確ではない。しかしながら，抗 MLCK 抗体で骨格筋を染めるとアクチン線維が染まる という報告がいくつかあり ${ }^{(5)}$ ，この方面からの研究が発 展することが期待される.

1) P. F. Dillon, M. O. Aksoy, S. P. Driska \& R. A. Murphy: Science, 211, 495 (1981); 221, 464 (1983).

2) P. J.Silver \& J.T. Stull : J. Biol.Chem., 257, 6145 (1982).

3）渡辺静婎：生体の科学，33，264（1982）.

4) G. A. Klug, B. R. Bottermann \& J. T. Stull : J. Biol. Chem., 257, 4688 (1982).

5) V. Guerriero, D. R. Rowley \& A. R. Means : Cell, 27, 449 (1981).

（矢沢 道生, 北海道大学理学部化学第二学科）

\section{卵が放出する精子受精能阻害物質}

\section{一一たたひとつの精子に受精を制限する要因を卵表層部の顆粒に求めて}

受精し発生して次の世代となるように，雌の成体が綿 密なプログラムに沿って作りあげた成果が卵である。そ の卵が他ならぬパートナーである精子を䭾目にするよう な物質を放出するなんて，妙な話だと思われるである う。しかし，卵はたったひとつの精子によって受精され れば十分なのであって，一旦受精さえすれば残りの多数 の精子はむしろ“迷惑な”存在となる。そこで，受精し た卵は何とかしてこれらの余分な精子を排除しょうとす る.このような機構を一般に多精防止と呼んでいるが, これには動物種によっていろいろな土夫がみられる。
こでは,このようなエ夫のひとつではないかといわれて いる精子受精能阻害物質とその放出について，この方面 での研究の最も進んでいるウニの卵の場合を例にして述 べてみよう.

ウニの成熟未受精卵は $2 つ の$ 被覆によって保護されて いる．外層はジェリー層とよばれ，そのままでは目で見 ることはできない。たとえばヤヌス緑とよばれる色素の 溶液に卵を入れると，この層が紫褐色に染まるのでその 存在がわかる.このジェリー層の内側に卵膜がある.こ れる，普通の光学頭微鏡では識別しにくい，たた，受精 
するとこの 膜が卵から離れていわゆる受精膜となるの で，初めてそれとわかるようになる。この卵膜の内側に 卵細胞膜 (卵原形質膜) があるのだが，これは光学顕微 鏡ではいよい上識別不可能となる。ところで，この卵細 胞膜の内側直下，すなわち卵原形質の表層部に表層粒と よばれる顆粒が多数密に配列している．この顆粒群は先 に述べたヤヌス緑で染まるので，染めたあと高倍率の光 学顕微鏡で観察することもできる.この表層粒こそ, こ れから述べる精子受精能阻害物質の貯蔵庫なのである.

表層粒は受精卵ではもら見ることはできない。受精す ると, 精子侵入点近傍の表層粒からまずこわれ始め, 順 次隣接する表層粒がこわれていって反対極のそれがこわ れるまで続くのである，この表層粒の崩壊，実はその内 容物の卵外への放出につれて，先ほどの卵膜が卵本体か ら離れ，それは全表面に及ぶことになる．暗視野顕微鏡 で観察すると，この表層粒崩填の “波”は光輝くリング (つまり卵の輪郭) の色調の 変化として認めることがで き, 古くから表層反応（表層変化）として多くの研究者 の注意をひいてきた。

この表層反応が受精膜の形成に深く関わることは，時 間的経過から容易に考えられることであり，また事実そ の通りなのであるが，その他に多精防止反応のひとつと しての意義が論議されている. 受精膜は形成されると硬 くなり，余分な精子はこれを通り拔けることができなく なるのだから，その意味ではこの反応が多精防止反応で もあることは確かなのであるが，これとは別の観点なの である.

表層粒にはいろいろな物質が含まれている.トリプシ ン様の蛋白分解酵素がこの顆粒中に見いだされてから， にわかにこの 観点がクローズアップされるようになっ た. 大豆から抽出されたトリプシン活性阻害物質によっ て, ウニ卵が多精になるといら結果が報告されたのは今 から四半世紀も前のことなのであるが，その本当の意味 は解らずじまいであった．表層粒内に貯蔵されていたこ の酵素は，表層反応の 結果卵外に 放出される．このと きすでに多数の精子は卵膜に結合している.この結合 をこの酵素が切断してしまうというわけである，実際， この精子と卵の結合にあずかる蛋白質（精子結合因子） はトリプシンによって分断される．また，この酵素は精
子と卵の結合を切るだけでなく，卵膜と卵細胞質膜との 間のつながりもはがし，前者が受精膜として卵本体から 離れるのにも役立っているという。これは，間接的にや はり余分な精子と卵を分けへだてることになる。

この説にはしかし難点がある．論者は受精膜が完成す るにつれて結合している余分な精子が受精膜から離れて ゆく現象を論拠のひとつとしているのであるが，しかし ウニの種類によっては必ずしもそうはいかないまた， 受精膜がうまくできず，ちょうど水胞のようにぶくぶく 状になって多くの場所で卵細胞膜とくっついたままの場 合もあるが，多精にならない場合が多い，甚しい場合は まったく受精膜ができない（卵から離れない）こともあ るが，やはり多精にはならない場合が多い（実は多精防 止には膜電位依存性の一過性で速い機構が別にあるのだ が,ここではこれにはふれない).

一方，表層粒にはパーオキシダーゼもあることがわか っている. この酵素は過酸化水素 $\left(\mathrm{H}_{2} \mathrm{O}_{2}\right)$ を基質として いる. このパーオキシダーゼも表層反応の 結果放出さ れ，受精膜の完成（硬化）に一役をになっているといわ れ，したがって精子の侵入を不可能にしているのだから 間接的にも多精防止にあずかっていることになるのであ るが, 問題は $\mathrm{H}_{2} \mathrm{O}_{2}$ のほうである.この $\mathrm{H}_{2} \mathrm{O}_{2}$ がやはり 表層反応の結果卵から放出される.この $\mathrm{H}_{2} \mathrm{O}_{2}$ が精子自 身も持っている（と考えられる）パーオキシダーゼと反 応して酸化物を作り，この酸化物が精子に作用して駄目 にしてしまうといら考觉が提出されている．この考穴に よると、“はぐれ”精子は自殺行為をとることになる. 実 際に海水中に放出された量とほぼ等濃度の $\mathrm{H}_{2} \mathrm{O}_{2}$ によっ て精子の受精能が急速に失われるという．まだ真偽のほ ぞは明らかではないが, 生物は複数の補償系を持ってい る場合が多いので，そのうちのひとつとして考えること はできる.

ここで，魚の卵のような精子の侵入点の限られた場合 に話を転じょう．魚の卵には卵門と呼ばれる精子侵入孔 が予め存在する. 複数存在するような種類もあるが（た とえばキャビアの材料であるチョウザメ卵では，数個か らときに数十個の卵門がある), 多くはひとつである. 多数の精子がこの孔から侵入するのであるが，末端部

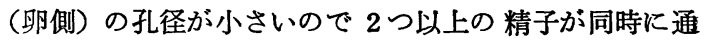


過することはできない，さて，2つ目以降の精子はどう なるか．表層反応がはじまって表層胞（表層粒に相当す る）の内容物であるコロイド状物質が放出されると，こ れらの精子は卵外へ押し出される。やや゙て卵門に栓がで きて，結局余分な精子は卵内には入れないことになる。 このコロイド物質のなかに，あるいはこの他に放出され る精子受精能阻害物質があるかどうかの研究は未だない が，ここで筆者自身の古い観察を紹介しておこう.メダ カの卵での観察である.卵門内につまった多数の余分な 精子は，コロイド物質によって卵門外へ排除されること は他の魚卵の場合と同様である. ただ，筆者が興味を持 ったのは排除された精子の振舞である．彼らは一旦まる で麻痺されたかのように卵門入口のところで“ボケー”

\section{陽葉緑体亡陰葉緑体}

\section{一一光合成装置の光環境への適応}

高等植物の葉緑体は，チラコイドと呼ばれる膜胞系と ストロマと呼ばれる礎質系が，二重の包膜に囲まれたオ ルガネラである．チラコイドの重った部分をグラナと呼 ぶ.グラナでチラコイドどうしが接着している部分の膜 (appressed region) には水分解系と光化学系 II（系 II） の成分が，ストロマに接しているチラコイド膜（nonappressed region) には光化学系 I（系 I）の成分と光 リン酸化共役因子が存在している，ストロマには，炭酸 固定系の諸酵素をはじめとする種々の酵素系が存在して いる. 本稿では, この葉緑体の話題を中心として, 光合 成装置の光環境への適応について述べょう.

まず，陽生植物と生性植物の葉緑体を比較しょう，陽 生植物は, 強光下に生育寸るのに対して, 陰生植物は, 上部の植被を透過して弱められた光一一波長組成として は遠赤光と緑色光が多い一の下で生育する．両者の葉 緑体を単離して，それらのクロロフィル当たりの光合 成・電子伝達活性を比較すると，顕著ならがいがみられ る. 陽生植物の葉緑体（陽葉緑体）の最大活性は高く, 飽和光強度も高いのに対して, 陰生植物の葉緑体（陰葉 緑体）のそれらは低い。したがって，陰葉緑体治強い光 のエネルギーを利用できない．この最大活性のちがい は，主に系 I の電子卮達鎖成分の含量のちがいによって
として，運動寸ることもなかった。しかし短時間に“目 覚め”，尾をビートさせて泳ぎ去ったのである．この観 察は特に筆者の印象に残っている．何時の日にかこの現 象を再確認し，もしこの時筆者が考えたように，卵が精 子を麻瘏させる物質を放出しているなら，この物質を単 離したいものだと考えている.

1）中埜栄三ほか編：‘発生の生化学’，裳華房，1979.

2）緋田研爾：“精子が卵化出会うとき’, 自然，1980 年 2 月号.

3）星 元紀：“卵之精子が融合するまで，科学，1980 年 8 , 9 月号.

4) 宮崎俊一: ‘受精々膜電位', 科学, 1980 年 6 月号.

5）毛利秀雄注か: 特集 “動物の受精', 遺伝，1983 年 7 月号.

（緋田 研䙲, 北海道大学臨海実験所）
いる. 陽葉緑体は陰葉緑体に比較して, クロロフィル当 たりのプラストキノン, チトクロム $f$, プラストシアニ ン,フェレドキシンなどの含量が高く，系 I の反応中心 （P 700）の含量もやや高い.さらに陽葉緑体では, 電子 公達活性に応じて光リン酸化や炭酸固定の活性も高く, これらに関連した酵素の含量も高い(1).

物質経済的に考えると，種々の成分の含量の高い，高 い活性の葉緑体を形成・維持するために，植物は多くの エネルギーを投入しなければならない，強光下では、コ ストに見合った光合成による利益があるが，光合成をあ まり行なえない弱光下では差し引きで損失となってしま う.それぞれの光環境下で，ぞの程度の活性を保持する のが最も効率的一適応的一であるかは，この兼合い によって決まっているようである.

大まかにいって, 葉緑体の色素は, 吸収した光のエネ ルギーを系Iにわたするのと系沉わたするのに分ける ことができ, 陽葉緑体と陰葉緑体ではそれらの比率が異 なる. クロロフィルは, 光化学系 I複合体, 光化学系II 複合体, 光捕獲性クロロフィル $a / b$ 蛋白質複合体 (LHCP-II) のいずれかに結合している．これらを穏や かな条件下の電気泳動で分離し，それぞれに含まれるク ロロフィル量を測定することができる. 光化学系II複合 
体と主としてこれに結合している LHCP-IIのクロロ フィル含量——系IIの色素含量一一を光化学系 I 複合体 のそれで割った值は，陰葉緑体のほうが陽葉緑体よりも かなり大きい(2).

電子伝達が正常に行なわれるためには, 系 I と系IIが ともに，片寄りなく励起されなければならない。系I と 系IIの励起スペクトルはほぼ重なるが, 遠赤部において 異なることはよく知られている——系遠赤色光では 励起されない，前述のように，陰生植物は遠赤色光の多 い環境に生育する。しかし，陰葉緑体には系IIにェネル ギーを転移する色素が多いので, 遠赤色光以外の光（主 として緑色光）によって系II も分励起され, 正常に電 子厷達を行ないらる. この点, 陰葉緑体における, 色素 の系IIへの㣂在は, 生育環境の波長組成への適応の結果 といえよう（系Ｉ と系IIへのエネルギー配分の調節は, state 1-state 2 transition と呼ばれる動的な機構によって も行なわれている. 系過㮃に励起されると，一部の LHCP-IIはリン酸化され, appressed region から押し 出され, non-appressed region へ移動する。 この状態で は，LHCP-IIは系Iにもエネルギーをわたす. 陰生植物 に急に直射日光があたった際などのエネルギー配分の調 節に重要な機構である(3) $)$.

以上述べたような陽葉緑体と陰葉緑体の成分のちがい は, 葉緑体の形態のちがいにも反映されている. 系I成 分の含量が高く, LHCP-II含量が低い陽葉緑体の チラ コイドは, non-appressed region の appressed region に対する割合が，陰葉緑体に拈汁るとれより高く，これ に伴い,グラナチラコイドの層数が陰葉緑体より少な い. 陽葉緑体ではグラナチラコイドは高々数層であるの に対し，陰葉緑体では 100 層にも及ぶことがある(4).

微視的には, 陽葉緑体と陰葉緑体は，1枚の葉の中に も存在する。一般に，葉は表側に大部分の光を受けてい る. 裹側にあたる光を実測してみると, 表から受ける光 のわずか数\%である. 表側から光をあてた時の葉の透過 率は，植物によって異なるが，ツバキでは $680 \mathrm{nm（ク}$ ロロフィルによる吸収の極大）で $0.1 \%, 550 \mathrm{~nm}$ で $3 \%$ である.このため, 葉肉組織のらち裏側に近い部分は, 深い森林の林床に匹敵するほど暗い. 滑走ミクロトーム を用いて，葉を削り，葉肉を表側（栅状組織）と裏側
(海綿状組織) に分けることができる. ツバキの 葉のそ れぞれの切片から葉緑体を単離し, これらの光化学系を 比較すると, 表側の切片から単離した葉緑体は陽葉緑体 の, 裏側の葉緑体は陰葉緑体の性質を示す ${ }^{(5)}$. ホウレン ソウ,タバュなどについても同様な葉緑体の分化がみら れるので, 背腹葉において 1 枚の葉の内部に陽葉緑体と 陰葉緑体とが存在することは一般的な現象であろう。葉 の内部における陽葉緑体と陰葉緑体の分化も, それによ って葉全体としての光合成の効率がよくなっているので 適応的である（さらに葉全体の光合成の効率をよくする ためには, 葉の内部に护ける光の配分パターンも重要な 役割を果たしている.これには柵状組織と海綿状組織の 形態のちがいに基づく光学的性質のちがいが大きな意味 をもっている(6)

以上概説したように，葉緑体はおかれる光環境によっ てその性質が変化し，その変化の結果は適応的である.

しかし，葉緑体に変化をもたらすメカニズムについては ほとんどわかっていない，この変化のための環境情報と して光強度が重要であることはいらまですないが，その 他にも青色光効果や, フィトクロム系による制御を示唆 する報告がある．前述のように，植被の下に到達する 光一一葉の内部においては組織を透過した光一の波長 組成は青色光や赤色光が少なく，遠赤色が多くなってお り，光質による制御も起こりえよう.いずれにしても， この分野の研究例は少なく, 今後研究をすすめる必要が あろら。

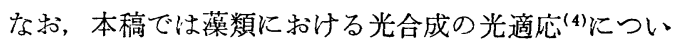
ては述べなかった．また, 強光による光合成系の阻害と

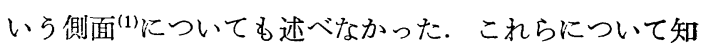
りたい方は，総説を参照していただきたい.

1) O. Bjcrkman : "Encyclopedia of Plant Physiology, New Series, Vol.12 A”, Springer, 1981, p 57.

2) J. M. Anderson : Photobiochem. Photobiophys., 3, 225 (1982).

3) J. Barber : Annu. Rev. Plant Physiol., 33, 261 (1982).

4）神谷明男: “葉緑体”, 宮地ら編, 理工学社, 1980, p. 311 .

5）寺島一郎：1983 年度植物生理学会講演要旨集, p. 273 , 投 稿準備中.

6) I. Terashima \& T Saeki : Plant \& Cell Physiol., in press.

（寺島 一郎, 東京大学理学部植物学教室） 


\section{肉の品質}

\section{一きめ, 硬軟, 保水性などに組織学的性状が影響}

肉質が良いか悪いか，あるいは望ましい肉質であるか 否かということは, 肉の価格, 加工製品の品質, 調理肉 の食味などを直接左右するため, 食肉にとって重要な問 題である. 通常, 肉質を判定する項目としては，きめ， 軟らかさ，筋肉内への脂肪の量と分布 (脂肪交雑) およ び質, 保水性. 肉色, 風味などがあげられる.では優れた 肉質の基準はどうかということになると，一概に言うこ とができない，肉質の基準は国や地域の食習慣により， 時代によって変わってくるし，また生産・流通・消費そ れぞれの立場淿よっても多少異なるので，一律に肉質の 基準を定めることはむずかしい，牛と豚の枝肉について は, 市場取引を安定・公正にするため枝肉取引規格が定 められ，肉質についても規格があるが，時代の推移に伴 って基準を変更せざるをえない状態である.

家畜体を構成している約 250 対の骨格筋が食肉となる が，いうまでもなく，筋肉は生体に扮いて運動の生理機 能をるつ器官である. したがって, 生命現象を形態的な 面から追究する組織学では, 当然のことだが筋肉の運動 機能についての研究が行なわれている。しかし，食肉， とくに肉質との関連で筋肉を組織学的に研究するには， 生物学や医学での組織学とは異なった面もあるはずであ る.以下，これらのことについて触れてみる。

各筋肉の全体流, 筋上膜 (epimisium) といわれる結 合組織によって包まれている，普通，筋膜といわれてい るものである．筋上膜から厚い中隔 (septum) が筋肉内 に入り，笳肉を区画する，外からの血管，神経，リンパ 管は中隔を走って筋肉内部に入る，また，筋線維は中隔 から中隔に走る．筋上膜あるいは中隔から結合組織が内 部へ入りこんで筋線維を区画する．区画された筋線維の 束を筋束 (fasicles) といい，筋束を包む膜を筋 周 膜 (perimysium) という．さらに筋周膜から個々の筋線維 を囲む筋内膜 (endomysium) が入る.

筋周膜には膠原線維の太い密線維性結合組織 (dense connective tissue) からなるものと, 膠原線維の細い疎 線維性結合組織 (loose connective tissue) のものとがあ
る. 前者の筋周膜は弾性線維を伴っている．筋肉によっ て膠原線維と弾性線維の発達に著しい差があり，肉のな かで最も軟らかい“ひれ”（腸腰筋と小腰筋）では両線雓 とも発達しないが，最も硬い肉である“しきんほ”（半 腱様筋）は両者とも発達している。また“そともも”（大 退二頭筋) では内側では弾性線維は発達しないが外側で は発達している。す初の筋は，膠原線維は多いが弾性線 維はきわめて少ない。ロース芯（胸最長筋）は膠原線維 は中等度で, 弾性線維は少ない,このように, 肉の軟ら かさの要因の 1 つに結合組織と，とくに弾性線維の量が あるが, 後述のように筋線維の性状も軟らかさに関与し ている.

筋束は筋線維が数十本集まって第一次筋束を形成して おり，それらが数十個集まって第二次筋束をつくる，肉 の研究の場合, 第二次筋束を筋束, 第一次筋束を筋小束 とした注うがよい，牛肉では，筋束の大きさは筋肉によ って異なり, 断面積で 5 40 $\mathrm{mm}^{2}$ で 10〜20 $\mathrm{mm}^{2}$ の大 きさのものが多い，この筋束の大きさが肉の “きめ”に なる. そして筋束内の筋線維数が多いほど——筋線維が 細いほど—肉はビロード状を呈し肉質が良い，

牛肉と豚肉で組織学的に最も異なる点が 2 つる。 そ の 1 つは筋肉内の血管の走行であり，他は筋線維型の配 列である. 前者は脂肪交雑に関連しているが, 後者につ いては不明である.

牛肉では, 中隔から筋束間の筋周膜へ入った血管は筋 周膜を縦走し，筋束中央部へ細血管を分枝する．筋束中 央部を 3〜4 $\mathrm{mm}$ 縦走した細血管は再び筋束外に出る. そして，別の細血管が筋束内に走っては出ていく．した がって，筋束中央部を絽走する細動・静脈は不連続であ り，笳肉の横断面の組織標本では筋束中央部に細動・静 脈が存在する筋束, 存在しない筋束, 筋周膜から筋束中 央部へ横行する細血管がみられる筋束なぞ，さまざまな 像がみられる，豚肉や舀肉では，筋束中央部を絽走する 血管の走行はみられない。

肥育をすすめると，体構成分は脂肪が増加し，水分は 
減少する. 一方, 蛋白質と灰分はあまり变化しないが, 脂肪增量が顕著になると蛋白質は若干減少する．この傾 向は筋肉でも同様である．豚や鷄でも同じである．脂肪 は皮下, 内臓, 筋肉間, 筋肉内に沈着する. 筋肉内に沈 着する脂肪を脂肪交雑といっており, 筇間脂肪は脂肪交 雑といわない. 牛肉では, 筋肉内脂肪沈着は筋束間への 脂肪沈着と筋束内へのものがあって, 脂肪交雑は筋束 内の脂肪沈着と定義したほうがよいように考学られる. 筋束内での脂肪組織は笳束内を縦走する細動脈と細静脈 の周囲に形成される.脂肪交雑が多くなると筋束中央の 脂肪組織の面積が増加するが, 品種や系統によって量が 異なる. 筋束間の脂肪沈着は, 蹯線維性結合組織の筋周 膜で多い, 密線維性結合組織の場では沈着がみられない が, 筋束間脂肪の非常に多い肉では, 膠原線維束の外側 に沈着がみられるようになる. 肉質からみると筋束間脂 肪は少なく、筋束内脂肪が適度のものが望をしい。しか し, たいていの肉では筋束間に多く沈着するもので筋束 内に沈着するが, 筋束間に少ない場合には筋束内に沈着 しない肉もある. 筋束内に脂肪細胞が形成されるか否か は，遺伝的支配をうけているょうである，豚肉では筋束 中央部に細血管が存在しないので脂肪交雑はなく, 筋束 間と筋間に沈着するだけである。

筋を構成している筇線維は均一ではなく, 組織化学的 に異質性を示す線維型が存在する. ミオシン ATPase の酸性側（pH 4.2〜4.5）に高い活性をるち, アルカリ 側 (pH 9.4〜10.5) では活性の低い筋線維を Type I, あるいは $\beta$ ，これとは逆の活性を示す筋線維を Type II あるいは $\alpha, \mathrm{A}$ 型という(1).これとは別に, 酸化酵素 活性高く, ホスホリラーゼ活性低く, グリコーゲン含有 少なく、ミトコンドリアとミオグロビンが豊富な細い線 維を red fiber, 反対のものを white fiber といい(2), あ るいはこれらの中間の特徵をもつ intermediate fiber が ある(4). また, Type A,B,C の線維型に分類し, 亜線維 型る各動物によって報告(4)されているなど, 線維型の多 様性はいまだに統一されていない，ここでは，Ogata と Mori ${ }^{(3)}$ による赤色筋線維, 中間筋線維, 白色筇線維の 線維型とする。

牛肉と豚肉では, 各線維型の配列が異なる.豚肉では 筋小束中央に赤色筋線維が集まって拉り, その周囲に中
間筋線維が存在し, 外側に白色筋線維が配列している. これに対して, 牛筋肉では赤色筋線維は散在していて豚 筋肉のような配列をとらない，これは，赤色筋線維のほ らがより血管と親和性があって酸素の供給を多くする必 要があるためで，血管走行と関係がある．この線維型の 配列のちがいが肉質とどのような関連性をもっているか は不明である。

豚肉では, 白色筋線維と中間筋線維は太さ, グリコー ゲン量, 酵素活性など屠体によって非常に差がある. 筋 線維が太く，グリコーゲン多く，酸化還元酵素活性が高 い屠体では肉質が良くない，これらは筋線維間に空隙が 形成される．内肉質の良いるのでは組織標本で筋線維間に 空隍はできず密着しているが, 保水性が減少するに従っ て筋線維間の空隙は広くなる. PSE 筋肉では, 筋線維の 萎縮をも伴う.したがって, 筋線維間の空隙を測定する ことにより保水性が推定できる. 以上のことは牛肉にお いても同じことがいえる.

赤色筋線維はグリコーゲンが少ないが，屠体によって は赤色筋線維でグリコーゲンが多く, 白色筋線維で消失 しているものがある．これらの筋肉では，赤色筋線維は 肥大し濃染する. そして, 筋線維周囲の結合組織線維は 増生する.このような肉は肉眼的には肉質が良いことに なるが，組織学的には劣悪な肉であるということにな る.

以上，肉質について組織学的所見を簡単に述べてきた が, 生体に括ける筋肉は肉の熟成を経過させて——物理 的・化学的・組織学的変化をさせて一一食肉にするの で, 生体時の筋肉から食肉となるまでの経過を調べるこ とによって正しい肉質に関する知見が得られる。これら の分野の組織学を食品組織学 (food histology) といって いる.

1) V.Dubowitz \& D. L. Newman : Nature, 214, 840 (1967).

2) V.Dubowitz \& A. G. E. Pearse : Histochemie, 2, 105 (1960).

[.3) T. Ogata \& M. Mori : J. Histochem.Cytochem., 12, 488 (1964).

4) A.Suzuki \& P. G. Cassens : Histochem. J., 12, 687 (1980).

(星野 忠彦, 東北大学農学部畜産学科) 


\section{植物における細胞間相互作用とホルモン}

\section{一一茎成長に見られる子葉亡茎の相関現象}

種子植物の個体発生の過程において，まず初めに形成 される葉が子葉である. 子葉には植物によって発芽後同 化器官として働くもの, 栄養分の貯蔵器官として働くも の，あるいは両方の働きを行なうものなどがある。した がって，発芽後まもない時期に植物がその子葉になんら かの原因で損傷を受けるとその後の芽生えの発育が悪く なるのは, 子葉から他の器官への栄養分の供給が十分に 行なわれなくなるためと考兄られてきた，ところが，子 葉は栄養補給器官として働くとともに，特殊な植物成長 物質を生産することによって芽生え，特に茎，の成長に 対する植物ホルモンであるジベレリンの作用を調節して いることが明らかになってきた。

ジベレリンの基本的な生理作用の一つは，細胞伸長， 特に茎細胞の伸長成長の促進である，たとえば，発芽後 2 日目のレタスの芽生えにジベレリンを与えると，茎の 成長速度は対照の約 5 倍にもなる。レタスの芽生えのジ ベレリンに対するこの反応は特異性が高く，ある濃度範 囲のジベレリンに対して成長量が比例するので，しばし ばジベレリンの生物的定量法に利用されている．ところ が，レタスの芽生えから子葉を切除してしまうとこのよ らなジベレリンの効果はなくなってしまうことを，筆者 らは発見した。しかし，子葉の浸出液を子葉を切除した 芽生えに与えると，子葉を持つ芽生えと同程度の伸長成 長がジベレリンによって起こることがわかった。これら の事実から筆者らは，レタスの子葉中にジベレリン作用 を助ける活性物質（子葉因子）が存在すると考光，その 抽出と精製を行ない，それがジヒドロコニフェリルアル コールであると同定した、レタスの子葉因子の発見の経 緯については, 本誌 11 巻 12 号の本欄炕すで詳しく 述べる機会があった ${ }^{(1)}$ ，そこで，子葉因子が発見されて から約 10 年たった今，その発見によって高等植物の成 長調節に関していかなる新しい事実が明らかになったか そついて述べてみたい。

子葉因子の構造が明らかになったので, 各種の子葉因 子の誘導体を合成してこれらの誘導体の構造と生理活性
との関係を検討することが可能となった(2). その結果，

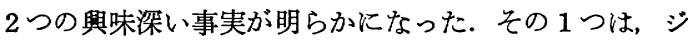
ヒドロコニフェリルアルコールの誘導体で高等植物に広 く分布していることが知られている桂皮酸やコーヒー酸 などが抗子葉因子としての生理作用を持ち、ジヒドロコ ニフェリルアルコールの作用を拮抗的に阻害することで ある ${ }^{(3)}$. もう 1 つは，子葉因子に構造が比較的よく似て いるノルエピネフリン，エピネフリン，ドーパミンなど のカテコールアミンが子葉因子様の生理活性を持ら,さ らにこれらのカテコールアミンの生理作用が抗子葉因子 によって強く阻害されることである(4).これらの事実か ら、レタスの茎成長に対するジベレリンの生理作用は, 内生の子葉因子と抗子葉因子の量的なバランスによって 調節されていることが示唆された. また, 抗子葉因子が 存在するという事実は, 子葉因子がその生理作用を発揮 するためには細胞内に存在すると想像される受容体に結 合する必要があることを示唆した，さらに，カテコール アミンとジヒドロコニフェリルアルコールの作用が共に 抗子葉因子によって強く阻害される事実から, 両者の受 容体は同じ物であることが示唆された。

生理活性物質としてのカテュールアミンは，主として 高等動物に拈ける神経公達物質として注目されてきた。 一方, 高等植物にもカテュールアミンとその誘導体が存 在することが知られているが，これらの化合物は薬理作 用のある植物アルカロイドとしてもっぱら注目され，そ れらを生産する高等植物自身の生理過程にどのような役 割を果たしているかはまだよくわかっていなかった。し かし，カテュールアミンがレタスの茎成長に対するジベ レリン作用を子葉因子と同様化高める働きがあるという 事実 ${ }^{(4)}$ ， 最近筆者らがレタスの芽生えからカテュール アミンの一種であるドーパミンを GC-MS 法で検出し たという事実 ${ }^{(5)} は$ ，カテュールアミンが植物の茎成長の 調節に関与していることを強く示している。また，神経 ホルモンであるカテュールアミンが子葉因子と同じ生理 活性をジベレリンによるレタスの茎成長に対して持つこ 
とから，他の神経ホルモンも同様な生理活性を持つので はないかと期待された. 事実, カテコールアミンの受容 体のブロッカー, あるいはセロトニンやアセチルニリン などの神経ホルモンが子葉因子様の活性を持つことが最 近わかった．これらの事実は，子葉因子の作用機構を解 明する上で大いに参考になると思われる。

ジヒドロコニフェリルアルコールは，レタスの子葉因 子として 1973 年に筆者らによって発見されたが，その 後レタス以外の植物にも存在することが他の研究者らに よって明らかにされている(6,7). また, 植物細胞の 分裂 活性はアデニン系のサイトカイニンによって調節されて いるが，以前から非アデニン系と想像されるサイトカイ ニンが高等植物に存在することが知られていた. 最近, カエデ属の植物におけるこの非アデニン系のサイトカイ ニンがジヒドロコニフェリルアルコールであることが英 国の Lee らによって確認された ${ }^{(7)}$. 彼らは, ジヒドロュ ニフェリルアルコールがオーキシンの存在下でタバュや ダイズの培養細胞の分裂を促進すること，またダイコン の葉の老化を抑制することを発見した．しかし，ダイコ ソとキュウリの子葉の成長試験, キュウリの子葉のクロ ロフィル生合成試験，あるいはアマランタスの色素生合 成試験などの代表的なサイトカイニンの生物試験では, ジヒドロコニフェリルアルコールはサイトカイニン様の 活性を示さないことがわかった.これらの事実から, Lee らは, ジヒドロコニフェリルアルコールの生理作用は既 知つ植物ホルモンのいずれとも異なっていると主張して いる(7).

近年の著しい分子生物学の進歩によって, 体制の単純 な単細胞生物の増殖機構は分子，あるいは細胞レベルで
明らかにされつつある. しかし，体制が複雑な高等植物 の成長調節機構を解明することは, 現在でも多くの困難 を伴う. その理由の一つは, 高等植物のからだが生理機 能や形態の異なるきわめて多くの細胞から構築されてお り, 各細胞の働きや成長は細胞間の相互作用によって調 節されているからである. したがって, 細胞間の相互作 用がどのよらな機構によって行なわれているかを解析す ることは，単細胞生物に比べると複雑な体制を持つ高等 植物の成長調節機構を個体レベルで解明する上で有力な 手段になりらると期待される. 事実, 茥成㝵に見られる 茎と子葉との間の相関現象を解析することによって子葉 因子が発見され，その結果我々がまだ知らなかった新し い調節機構の存在が明らかにされた，高等植物に見られ る相関現象のように多くの要因を含む実験系でクリアー カットな結果を得ることはなかなか困難なことである. しかし，高等植物の相関現象の解析がさらに進められる ことによって，単細胞生物を用いたのでは解き明かすこ とのできない生命の仕組みが解明されることを期待した W.

1）神阪盛一郎，柴田耕造：化学と生物，11，780 (1973).

2) K. Shibata, T. Kubota \& S. Kamisaka : Plant Cell Physiol., 16, 871 (1975).

3) S. Kamisaka \& K. Shıbata: Plant Cell Physiol., 18, 1057 (1977).

4) S. Kamisaka : Plant Cell Physiol., 20, 1199 (1979).

5) S. Kamisaka \& K. Shibata: Plant Grouth Regul., 1, 3 (1982).

6) R. Higuchi, M. Arıtomi \& D. M.X. Donnelly : Phytochemistry, 16, 1007 (1977).

7) T. S. Lee, J. G. Purse, R. J. Pryce, R. Horgan \& P.F. Wareing: Planta, 152, 571 (1981).

（神阪盛一郎, 大阪市立大学理学部生物学教室)

\section{嫌気的発醳による罹病作物残さの無毒化}

\section{一ビニル被覆による密封処理で病害菌が不活化。実用的技術としての確立に期待}

罹病作物残さ，すなわち発病被害作物体内には多量の 病原が存在し，そのまま放置すれば次作への伝染源とな る. 病害予防の上で, これらの適切な処理が重要である ことは古くから指摘されてきた. 現実には, 䍜病残さは そのまま土壤中にすき込まれることが多く，その結果， 多くの野菜産地で土壤病害を主体とする連作障害の激発
を招いている．適切な 処置が行なわれなかった 背景に は, 社会的経済的要因もあろらが，実用的な罹病残さ処 理技術が未確立であったことも見のがせない. 最近，そ の重要性を再認識する立場から, 罹病残さ除去が次作の 発病に及ぼす影響や，罹病残さ処理技術についての検討 が行なわれている(1). 
羅病残さを粗場から除去するだけでは，すでに発生し ている土壤病害を直ちになくすることはできない。しか し，発病のま九延・抎大が抑制され，また他の防除法と 併用したり，継続実施することによって防除効果が高ま る ${ }^{(1)}$. 一方, 野菜の多くは, 収檴後に多量の作物残さ （収檴残さ）を生じ，その量はしばしば収檴量に匹敵す る.これらは，有機質資源として活用することが望まし いが，利用の際にその中に含まれる罹病残さの処理が問 題となる．原理的には，羅病残さのみを処理すればよい が，実際上は不可能であり，適切な処理を行なおうとす るならば，収穫残さ全体を対象とせざるをえない，土壤 病害の発生は，ある時点で突然多発するるのではなく， 何らかの原因でごく少量圃場内に持ち込まれた病原が土 壤中で増殖し, あるいは活性を増大して, 被害が顕在化 し，次第に激化してゆく．罹病残さ除去の効果が予防的 傾向が強いことを考它わせると, 病害発生の確認以前 から収擭残さの処理を恒常的に行ならことが，病害発生 の予防あるいは発生後の急激なまん延を防ぐことになる う。そこに，多量の収穫残さを簡便に処理できる実用的 技術の開発が要望される所以がある.

これまでに実施あるいは検討されてきた主な罹病残さ 処理技術として，投棄，土中埋没，飼料化，焼却，加 熱, 堆肥化がある ${ }^{(1)}$. 投棄は他围場への污染拡大の危険 性を伴い，焼却，加熱，埋没処理は多くのエネルギーを 要し, 飼料化, 堆肥化は時に無毒化が不充分で再污染の 可能性を有するなど，それぞれにさらに検討すべき点が ある、筆者らは, ダイコン萎黄病を材料として, 堆肥化 処理による無毒化について検討した際に，䍜病残さが嫌 気的汇発酵する過程で本病菌が不活化することを見いだ した ${ }^{(2,3)}$.ここでは，本現象の発見に至った経過と本現 象を利用した新しい罹病残さ処理技術の可能性について 述べる.

嫶肥化処理による無毒化は, 植物病原菌の多くが $50^{\circ} \mathrm{C}$ 以上の湿熱によって比較的短時間内に 死隇するこ とを利用している. 堆嫧内部では $60 \sim 70^{\circ} \mathrm{C}$ の温度が少 なくとも 1 日間以上持続され，病原菌は死隇する。しか し，堆積の周縁部の温度はそれほど上昇せず，この部位 に存在する病原菌は生き残ってしまう。そこで筆者ら は，嫶積全体をビニルフィルムで包むことにより周縁部
まで高温化できるのではないかとの想定の下に，ビニル 被覆の有無別に罹病残さを堆積したところ ${ }^{(2)}$, 開放堆積 では，中央部は最高 $60^{\circ} \mathrm{C}$ 以上となったが，周縁部は $40^{\circ} \mathrm{C}$ 以下で, 中央部に和汸る羅病株中の病原菌は死隇 したが周縁部では生存していた。これに対し、ビニル 被覆により密封した堆積では, 内部温度はどの 部分も $35^{\circ} \mathrm{C}$ 以上とはならなかったにもかかわらず，罹病株中 の病原菌はごく一部分を除いて生存ぶ 確認できなかっ た.つまり, 密封処理によって周緑部の高温化といら目 的が達せられなかった代わりに，20〜30 $\mathrm{C}$ の常温下で も病原菌不活化の可能性が示唆された.

ところで, 20 日間の 密封堆積後に得られたダイコン は，あたかもサイレージに似た状態になっており，ビニ ル被覆により嫌気的発酵が進行したものと考兄られた。 そこで，ポリエチレン袋中に罹病根を詰め，10，20, $30^{\circ} \mathrm{C}$ の 3 段階の温度下に保ち, 病原菌の 活性を検討し てみた ${ }^{(3)}$. 罹病根からの病原菌検出率と, その発病力は ともに, 時間の経過に伴って低下し, ついには認められ なくなった。この低下は，温度が高い汪ど速く，pH の 低下すなわち嫩気的発酵の進行と並行する.このことか ら, ダイコン萎黄病菌は, ダイコンの嫌気的発酵の過程 で不活化するものと結論された。

さて, この不活化は一時的で, 再び活性化する恐れは ないのだろらか. 発酵処理後の罹病残さを土㗧に 混入 し，これにくり返しダイコンを栽培したところ，100 1 か月間発酵処理の 場合はわずかに 発病が認められた が， $10^{\circ} \mathrm{C} ， 2$ か月間あるいは $20^{\circ} \mathrm{C}$ 以上， 1 か月間以上 の発酵処理では 3 作目（1年後）までまったく発病しな いので, 病原菌は死隇したものと考学ら礼る(4).

以上の上うに，ダイコン萎黄病菌はダイコンの嫌気的 発酵の過程で抢そらくは死隇し, 本病䍜病残さは無毒化 されることは明らかである.この現象は, 塩化ビニルフ ィルムなどの被覆資材を用いて罹病残さを密封するだけ で生じ，野菜のように水分含量が著しく高い場合にも適 用が容易で，処理生成物の有機質資源としての再利用が 可能であり，環境条件にさほど制約されないなど，実用 的技術として応用するために多くの利点を備えている. 現段階では種々の検討課題が残されており，その中で も, 本現象の発現を促進する条件の解明, ダイコン萎黄 
病以外の病害に対する適用性, 処理生成物の土壤への還 元法とその作物に対する影響などが重要であろう。これ らの検討は緒についたばかりであるが，たとえば不活化 の進行に温度の影響が大きいこと ${ }^{(3)}$ (上述), 残さ発酵の 過程で污染土の発病力も同時に低下するので，污染土が 混入してもさしつかえないこと(5)，著しく水分含量が高 い場合でも不活化されること (未発表)，キュウリつる 割病菌やハクサイ根こぶ病菌も不活化すること（未発 表)，発酵生成物を土境に還元した場合，その直後には 作物の生育を阻害するが，この阻害作用は次第に消失す ること（未発表）などがほぼ明らかになっており，今後 検討を重ねることによって，実用的技術として確立でさ るものと考えられる.

連作による土壌病害の多発生が， ある意味で日本の野
菜栽培の宿命であるとすれば，羅病残さの適切な処理は 病害のまん延防止や病原菌密度低下をはかる有力な一手 段であり，栽培技術の一環として位置付けられねばなら ない，罹病残さ処理技術についてのさらに多くの研究が 望まれるところであり，ここに紹介した嫌気的発酵によ る罹病残さ処理技術の確立もその一翼を担うであろうこ とが期待される.

本稿の校閲をしていただいた竹内昭士郎室長（野菜試）, 執 筆を锥めてくださった土居養二教授（東大農）ならびに寺中理 明教授 (宇大農) に梁く感謝いたします。

1）萩原 廣: 植物防疫, 37, 405 (1983)。

2）萩原 廣, 竹内昭士郎：日植病報，48，688 (1982).

3）萩原 廣, 竹内昭士郎：日植病報, 49(5), 印刷中 (1983).

4）萩原 廣, 竹内昭士郎: 日植病関西部会講演要旨, 1983.

5）萩原 廣，竹内昭士郎：日植病大会講演要旨， 1983.

（萩 原 廣，農林水産省野菜試験場）

プロフィル

非田 研爾 (Kenji Aketa) 昭和 3 年 11月25日生<略歴>昭和 28 年名古屋大学 理学部生物学科卒業 $/ 32$ 年同大学理学部 助手, その後助教授を経て, 56年北海道 大学理学部教授, 現在にいたる.この間, 37〜38年イタリアパレルモ大学客員研究 員<研究テーマと抱負〉受精の生理化 学, とくに卵と精子の相互作用物質に注 目している. 他に老熟卵の回生法の開発 も進めているく趣味 >音楽鑑賞, オーデ イオ

入江 昌親 (Masachıka Irie) 昭和 6 年 7 月 10 日生 <略歴>昭和 28 年東京大 学医学部薬学科卒業 $/ 33$ 年同大学大学院 化学研究科博士課程修了(薬学) $/ 34$ 年同 大学薬学部助手 $/ 41$ 年京都大学薬学部助 教授 / 48 年星薬科大学微生物 学教 室教 授，現在にいたる。この間，35年米国カ リフォルニア大学生化学部留学く研究テ 一マと抱負>1）リボヌクレアーゼの構 造と機能について少しであ明確にした い.また，ヒト，ウシなどのリボヌクレ アーゼの分子種分布の生理的意義などに 興味をるっている. 2) グルコアミラー
ゼの構造と解明にも興味があるく趣味〉 散歩, 読書

上田誠之助 (Seinosuke Ueda) Vol 19, No.12, p. 791 参照

江藤 守総 (Morifusa Eto) Vol. 16, No.4, p. 226 参照

神阪盛一郎 (Seiichiro Kamısaka) 昭和15年11月11日生<略歴>昭和39年大 阪市立大学理学部生物学科卒業 $/ 41$ 年同 大学理学部修士課程修了 $/ 43$ 年同大学理 学部助手 $/ 47$ 年理博 $/ 48$ 年同大学講師 $/$ 49年同助教授, 現在にいたる.この間, 45年オーストラリアマクオリー大学, 50 年デンマークオーフス大学に留学く研究 テーマと抱負〉植物ホルモンジベレリン の作用機作の研究<趣味 >推理小説と酒

近藤 鍊三 (Renzō Kondō) 昭和 17 年 3 月 16 日生 <略歴>昭和 39 年帯広畜産 大学畜産学部総合農学科卒業／同年同大 学畜産学部助手, 現在にいたる. 農博 <研究テーマと抱負〉植物珄酸体の農学 および理学への応用, 泥炭土壤の有機物
の化学的性状の研究から泥炭士の開発と

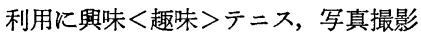

住友宏 (Hıroshi Sumitomo) Vol. 15 , No.7, p. 478 参照

左右田健次 (Kenjı Soda) Vol.20, No.7, p. 452 参照

高橋 学 (Manabu Takahashi) 昭和 7 年 2 月 6 日生 $<$ 略歴>昭和 32 年京 都大学医学部医学科卒業後, 付属病院に てインターン. 修了と同時に, 山口大学 医学部 (元山口県立医科大学) 病理学教 室助手となり, 講師, 助教授を経て，47 年教授，現在にいたる.この間，43〜45 年米国ペンシルバニア大学医学部 (Mendelsohn 教授) 留学く研究テーマと抱 負>テーマ: 癌細胞増殖の解析（とくに クロマチン構造と増殖性との関係につい て), 病理データの電算機処理. 関心: 細胞の増殖と分化に 関する 熱力学的解 析, 細胞状態方程式 (Leontieff 体系の 応用）〈趣味>クラシック音楽鑑賞（ほ とんど病気), 応用数学 